\title{
A fától az erdőt: Az információközösség fogalmának értelme és szükségszerüsége
}

(Egy hajdanvolt tudósvita nyomában)

Hogyan modellezzük az individuális tudattartalmak individuumok feletti közösségi mintázatokká való összekapcsolódását? A szerző az eddigi megoldásokhoz képest új oldalról közelíti meg a kérdést: a különbségek levezethetőségét nem egyszerűen ugyanolyan fontosnak tartja, mint az azonosság kérdéskörét, hanem egyenesen nélkülözhetetlennek, az azonosságok és a különbségek ugyanis egyaránt ugyanarra a közös magyarázó mechanizmusra vezethetőek vissza. Kimutatja, hogy négy rétegből (fizikai attribútum-kombinációk, individuális tudattartalom-kombinációk, kulturális kódok és tartalmak kombinációi, reflektív csoportfogalmak és azok kombinációi) származnak azok az információs alakzatok, amelyeknek a rekonstrukcióival információközösségek definiálhatók, a viselkedések különbözőségét pedig az információközösségek „metszéspontjai” értelmezik.

Kulcsszavak: Információközösség, azonosság és különbözőség, kulturális kód, attribútumok, csoporttudat, William McDougall, Robert Maciver

\section{Szerzői információ:}

\section{Z. Karvalies László}

Történész, az információs társadalom kutatója a Szegedi Tudományegyetem Könyvtártudományi Tanszékének tanszékvezető egyetemi docense, az ITTK (Információs Társadalom- és Trendkutató Központ) volt igazgatója, 2006-tól örökös tiszteletbeli elnöke. Számos kurzust dolgozott ki az információs társadalommal kapcsolatos ismeretek oktatásához, e tárgyban több szakkönyv és tanulmány szerzốje. A Kar Kiváló Oktatója (1999), Széchenyi-ösztöndíjas (2000-tól). Fontosabb könyvei: Fogpiszkáló a hálóaaton (2000), Az információs társadalom keresése (2002), Információ, társadalom, történelem (2003), Bevezetés az információtörténelembe (2004).

E-mail: zkl@itm.bme.hu

Így hivatkozzon erre a cikkre:

Z. Karvalics László. „A fától az erdőt: Az információközösség fogalmának értelme és szükségszerüsége”. Információs Társadalom VIII, 4. szám (2008): 55-72.

$=$ https://dx.doi.org/10.22503/inftars.VIII.2008.4.11 $\rightleftharpoons$

A folyóiratban közölt müvek

a Creative Commons Nevezd meg! - Ne add el! - Így add tovább! 4.0

Nemzetközi Licenc feltételeinek megfelelően használhatók. 
Z. Karvalics László

\title{
A fától az erdôt: \\ Az információközösség fogalmának értelme és szükségszerúsége
} (Egy hajdanvolt tudósvita nyomában)

\begin{abstract}
„Az egyes ember és a közösség élménye közti analógia nagyon tág. A közösség gondolkodása, érzése és akarása az egyes emberén nyugszik, mivel olyan folyamatok és szokások hatnak lelkére, melyek megint csak az egyes ember folyamataival és szokásaival analógok (megfelelnek nekik - szinte mintázzák azokat). Nevezetesen az eszmék szerepe azonos itt is és ott is. Egyrészt az a feladatuk, hogy az egyes embert, ahogyan a közösséget is, a valósággal összhangban tartsák, mely mind a logikában, mind a kutatómunkában kifejezésre jut, ami nem más, mint a kollektív érzékelés és ennek tárgyilagos feldolgozása, másrészt az eszmék kapcsolatban állnak az érzelmekkel, ezeket képviselik (tükrözik), de irányítaniuk és végül egy erốs egységbe is össze kell foglalniuk óket, és ennek az egységnek kívül és belül alkalmazkodónak, mégis alkotónak kell lennie."
\end{abstract}

Robert Musil: A tulajdonságok nélküli ember ${ }^{1}$

Noha a „kollektív intelligenciával”, a csoporttudattal kapcsolatos korai elképzelések már régóta a tudománytörténeti panoptikumba kerültek, azt a legáltalánosabb kérdést, amit mai formanyelven úgy tennénk fel, hogy miként kapcsolódnak össze az individuális tudattartalmak individuumok feletti közösségi mintázatokká, a csoporttudat fogalmának pušta elvetésével még nem válaszoltuk meg.

Az ezredforduló egyik legtermékenyebb új narratívája, a „tömegek bölcsessége”2 (wisdom of crowds) látszatra már létével is ugyanerre az intellektuális kihívásra válaszol, hiszen éppen azt fürkészi, miként képes bizonyos esetekben gondolkodó elmék egy véletlenszerúen vagy tudatosan megválasztott csoportja magasabb problémamegoldó értékủ tudást produkálni, mint a mégoly felkészült egyesek. Egyértelmú, hogy a csoportos problémamegoldásban valóban mindig jelen van valamiféle „transz-perszonális", ám ez nem más, mint $a z$ individuális teljesítmények összeadódásával elért többlet. (Ez természetesen igaz a Musil-mottó „,kollektív érzékelés”-fogalmára is.) E ,többlet” vagy „pluszhozadék” abból fakad, hogy a problémamegoldásba bevont különböző elmék által produkált megközelítésbeli, felfogásbeli sokszínúség az erôsen diverzifikált háttértudásokkal, elốismeretekkel kiegészülve „felülmúlja” a szükségképpen korlátozott kapacitású egyéni elmeteljesítményeket. ${ }^{3}$ Nagyon találónak tartom Marcus Anthony friss

\footnotetext{
${ }^{1}$ Idézi Zalán Péter: Musil világa. Bp., 1981, Európa, 167.

${ }^{2}$ Surowiecki, James: A tömegek böcsessége. Bp., 2007, Napvilág Kiadó.

${ }^{3}$ Page, Scott E. 2007. Difference. How the power of diversity creates better groups, firms, schools and societies. Princeton University Press.

${ }^{4}$ Marcus, Anthony 2008. The Case for integrated intelligence. In World Futures, Volume http://www.informaworld.com/smpp/title $\sim$ content $=\mathrm{t} 713393663 \sim \mathrm{db}=\mathrm{all} \sim \mathrm{tab}=$ issueslist $\sim$ branches $=64-\mathrm{v} 6464$, Issue 4 May, 233-253.
} 
(2008-ban publikált) fogalmi újítását, ${ }^{4}$ hiszen az általa bevezetett ,,integrált intelligencia" (integrated intelligence) szellemesen kapcsolja össze a régi és az új diskurzusokat. Ezekhez - régiként - feltétlenül oda kell sorolnunk a „világagy” (global brain) közel nyolcvanéves irodalmát ${ }^{5}$ és - újként - a ,kollektív intelligencia” újraélesztett fogalmából kiinduló közösségelméleteket. ${ }^{6}$ Ezek közös jellemzóje az, hogy voltaképpen az integrált intelligencia fogalmát alkalmazzák különféle speciális közösségekre (a „világagy"-koncepció például az emberiség egészét felöleli).

Az így kialakuló vízgyưjjtő medencébe további három, kiindulópontjaikban eltérő, de eredményeikben összefutó tudományos iskola szállít friss gondolatáramlásokat.

A kollektív viselkedést és cselekvést (collective behavior and action) magyarázó okokat nem szúnő́ kedvvel kutató pszichológusoknak ${ }^{7}$ már évtizedekkel ezelốt sikerült olyan fogalmi teraszt építeniük, amellyel a leírás számukra fontos csomópontjain elégséges magyarázatot tudnak adni a viselkedési minták azonosságára. Az ô megoldásuk az általánosan elterjedt vélekedések és hiedelmek, szabályok és kódok (generalized beliefs) fogalmának bevezetése, illetve többdimenziós és többváltozós mozgósítása.

Nagyon hasonló megoldásba szaladtak bele egy viszonylag új ismeretelméletilogikai-filozófiai-tudásszociológiai irányzat legjobbjai, amikor a „hogyan lehetséges megértés különböző élethelyzetekben" kérdésének felvetésével választ kerestek a viselkedések koordinálhatóságát biztosító mechanizmusok mibenlétére. Ehhez vezették be a közös tudás (common knowledge) és kölcsönös tudás (mutual knowledge) kategóriáit. ${ }^{8}$ Ugyanezt a társas viselkedést irányító funkciót írja le a konvenció Hume után néhány évtizeddel ezelö́tt újrafelfedezett fogalma, ${ }^{9}$ és ugyanígy jut el a kulturális antropológia a szimbólum szuperfogalmához, amely „szimbolikus formákban kifejezett örökölt koncepciók azon [...] rendszere, amelynek segítségével az emberek kommunikálnak egymással, állandósítják és fejlesztik az élettel kapcsolatos tudásukat és attitúdjeiket". ${ }^{10}$ A pszichológusok társas megismerés fogalma valójában a „társas helyzetek” megértéséhez és kezeléséhez szükséges összefüggésekre vonatkozik. ${ }^{11}$ Nem lehet azonban nem észrevenni, hogy valamennyi megoldás a transzperszonális tudattartalom puszta megnevezésével mint a kutatási folyamat végén „meglelt” és az egyenlet hiányzó helyére beillesztett elemmel érzi immár teljesnek a képletet.

Ennek a megközelítésnek a végletekig vitelével született meg az egyszerre divatos, izgalmas és termékeny mémelmélet, a memetika, amely már a teljes komplexum központi magyarázó elvévé emeli a kultúrgént, a mémet. A memetika elsősorban (sốt

\footnotetext{
${ }^{5}$ Hagyományosan H. G Wells 1937-es World Brain címú novellájával kezdôdik a diskurzus, de a „társadalomelméleti narratíva” Wells említése nélkül is épül. L. Russell Peter 1976. The Global Brain. Los Angeles, J. P. Tarcher.

${ }^{6}$ Ilyen Pierre Lévy elsố nagyhatású munkája: Collective Intelligence. Mankind's emerging world in cyberspace. 1997, Perseus Books.

${ }^{7}$ Összefoglalóan 1. Smelser, N. J. 1962. Theory of collective behtvior: The Free Press, elsősorban 79-83.

${ }^{8}$ Leggazdagabb kifejtését ld. Vanderschraaf, Peter 2002. Common Knowledge. The Stanford Encyclopedia of Philosophy (Summer Edition). Ed. Edward N. Zalta. http://plato.stanford.edu/archives/sum2002/entries/common-knowledge/

${ }^{9}$ Minderról részletesen l. cbben a lapszámban Pete Krisztián: A társadalmi konvenciók természetéról.

${ }^{10}$ Clifford Geertzet idézi Kapitány Ágnes és Kapitány Gábor: A szimbólum arcai. Jel-Kép, 2008, 2. sz,, 65.

${ }^{11}$ L. David L. Hamilton - Susan T. Fiske - John A. Bargh 2006. A társak és a társadalom megismerése. Budapest, Osiris Kiadó.
} 
szinte kizárólag) a tudattartalmak tömegesedésének természetrajzára érzékeny, akár utánzásnak (Blackmore) ${ }^{12}$ akár járványszerú átvételnek (Sperber) ${ }^{13}$ tekinti azt a folyamatot, amelynek során egyre több individuális elmében jelenik meg ugyanaz a tudattartalom.

Találónak tưnik a csoporttudatról folyó vita elsố szakaszát a genetika történetéhez hasonlítva „mendelinek” nevezni. Az „emberi szemmel megtapasztalható” kollektív megnyilvánulások anatómiájára LeBontól McDougallig sokan kerestek boldog buzgósággal magyarázó elveket „,a jelenségeket képességeknek, a motívumokat ösztönöknek tulajdonítva", ${ }^{14}$ miközben az elme és az idegrendszer múködési mechanizmusairól még gyakorlatilag nem állt rendelkezésre tudományosan megalapozott elmélet. (Vagy ha volt is ilyen - mint például a neuront felfedezô Ramón y Cajal mind szélesebb körben ismert eredményei -, azt a bôsz elméletalkotásba belefeledkezett, játékos kedvú társadalomkutatók nem ismerték vagy nem vették figyelembe).

A csoporttudat-kutatás „watson-cricki” szakaszának, a DNS-re és a kettốs spirálra épülő leírás rendszerszintjének a bevezetóben bemutatott elméletek feleltethetók meg. A Dawkins köpenyéból kibújt mémfogalom egyenesen genetikai parafrázis, és a többi elmélet is vissza-visszatükrözi azt a (fóleg az agykutatás és a kognitív tudományok elôrehaladása révén megismert) tudást, amely az érzékelés, az emlékezet és az információkezelés idegrendszeri folyamataira való rálátás eredményeit modellszerúen volt képes beépíteni az elemzésekbe.

Ebben a tanulmányban négy egymással szorosan öszefüggó hipotézis első kifejtését kísérlem meg.

1. Eljött az ideje annak, hogy a genetikához hasonlóan $a$,csoporttudat"-diskurzus is a Watson-Crick utáni szakaszába lépjen. Ahogy a teljes genomtérképekkel, az új szekvenáló eljárásokkal vagy a „szemét DNS” (junk DNA) szerepének vizsgálatával elkezdtünk a korábbiaknál nagyságrendekkel nagyobb felbontású képet kapni az öröklési folyamatról, ugyanúgy jött el az ideje a „fekete doboz” felnyitásának a humán információs folyamatok esetében. A különös, de nem meglepố ebben az, hogy a „paradigmaváltás” mindkét esetben mennyiségi kihívással kapcsolódik össze. A genetika új eredményei mögött már minden esetben hatalmas komputációs kapacitásokat találunk, és számos területen forrt össze elválaszthatatlanul az informatika és a biológia.

Már az egyes ember információs mikrokozmosza is elképesztô számú halmazt jelent, hát még a valamennyi ember által együttesen alkotott információs univerzum! És ehhez adódik hozzá az a kizárólag halmazelméleti formanyelven megragadható sajátosság, hogy emberek különbözô méretû́ csoportjai információk különböző nagyságrendú kombinációival rendelkeznek. Az embereket és az általuk birtokolt információkat közösen leíró fogalmi és strukturális tér elborzasztóan összetett, nem véletlen tehát, hogy ide mindeddig nagyon kevesen merészkedtek. ${ }^{15}$

${ }^{12}$ Susan Blackmore 2001. A mémgépezet. Kulturális gének - a mémek. Magyar Könyvklub.

${ }^{13}$ Dan Sperber 2001. A kultúra magyarázata. Naturalista megközelítés. Osiris Zsebkönyvtár.

${ }^{14}$ Ezért nevezhette Osgood „az ócskaságbolt pszichológiájának” ezt az időszakot. Ld. Elizabeth R. Valentine 1988. Fogalmak és nézöpontok a pszichológiában. Bp., Gondolat.

${ }^{15}$ Pedig a természettudományok felól nézve is ez a „felbontás” volna indokolt. „...Az élet energetikai folyamat [...] a szellemi és lelki történések hordozói szintén [...] parányi elektromágneses erôhatások, így a lélek és az értelem kulcsa, hasonlóan a mesterséges intelligenciához, ezekkel az erốhatásokkal és az általuk 
2. A watson-cricki csoporttudat-elméletek egyaránt hibásak abban, hogy a fenti komplexumnak csak az egyik (jellemsóen az információs) vetuiletére érzékenyek. Pedig az információ kizárólag az azt belsóvé tevố (in-formáló) emberi tudatban létezik, és az emberi agy+információ ugyanúgy elválaszthatatlan egymástól, mint ahogy az élố rendszerek is kizárólag az élố anyag+a genetikai kód (, masina+šöveg") összekapcsolásával értelmezhetók, ${ }^{16}$ legalábbis módszertani egyoldalúság nélkül. ${ }^{17}$

3. A watson-cricki csoporttudat-elméletek elmarasztalhatók abban, hogy szinte csakis a tudattartalmak és cselekvések azonossága mögött munkáló felhajtóerók érdeklik óket. Megpróbáljuk kimutatni, hogy a különbségek levezethetósége nem egyszerúen ugyanolyan fontos, mint az azonosság kérdésköre, hanem egyenesen nélkülözhetetlen: $a$ \& $a$ zonosságok és a különbségek ugyanis egyaránt ugyanarra a közös magyarázó mechanizmusra vezethetốk vissza.

Természetesen van számos olyan tudományterület, amely éppen a viselkedések vagy a tudások csoporton belüli különbségére érzékeny: ilyen az intelligenciakutatás, a kreativitás faggatása, a kriminalisztika és fóleg a pedagógia néhány fejlett ágazata. Az azonosságok és különbségek egyidejú vizsgálatára nagyon kevesen vállalkoznak, ezért is különösen figyelemreméltók az alábbi megállapítások:

„[...] az emberekben felnôtté érésük során a közös tapasztalatok, közös ismeretforrások, élő és írott szó alapján kifejlődik a kifejezésnek és a megértésnek bizonyos egyöntetúsége. Ennek köszönhető, hogy az egy nyelvet beszéló emberek általában megértik egymás beszédét, durva félreértések nemigen fordulnak eló. Gyermekeknél más a helyzet, az utak még nem kijártak, az „egyöntetúség” még nem alakult ki. Ez teszi lehetôvé a felnótt számára egyértelmú kifejezések különbözô értelmezését." 18

Természetesen nem a gyermeki lét az egyetlen különbségképzố erố, de a fenti idézet nagyon jól illusztrálja a két oldal bátran dialektikusnak nevezhetố viszonyát, és egyúttal arra a dinamikára is rávilágít, amely a különbségek megszüntetésére gyakorolt nyomás sokféle mechanizmusán keresztül egyfolytában a minél teljesebb azonosság elérésén munkálkodik.

szükségszerúen kialakított dinamikus struktúrákkal értelmezhető.” L. Géczy István 1994. És mégis van Örökmozgó! avagy mitól mozog az Univerzum? Előadás a MÁFI Filozófiai Vitakörén. jan. 28.

${ }^{16}$ Gánti Tibor 1989. Kontra Crick, avagy Azélet mivolta. Budapest, Gondolat Kiadó.

${ }^{17}$ Arról nem is beszélve, hogy bármilyen információs jelensćg kizárólag cselekvéselméleti beágyazással vizsgálható, és mivel az információs körfolyamat a környezetre reflektál, a cselekvést és/vagy a környezeti mozzanatokat nélkülözô leírások szükségképpen „kilúgozottak” és elégtelenek. Erre 1. Z. Karvalics László: A démon törölközôje - Bevezetố megfontolások az információ mibenlétének tisztázásához (1.) In Víllalat, információ, tudomány. 2002. Szerk: Kiss F. - Egerszegi K. - Rácz Cs. Budapest, BME GTK ITM- KFKI, 5-14. (Alma Mater 4.)

${ }^{18}$ Hermann Alice a csoporttudat-kutatás mendeli szakaszából származó elképzelést gondol tovább, nevezetesen Karl Marbénak a lelki történés egyöntetúségéról (Gleichförmigkeit des psychischen Geschehens) vallott nézetét, részben - helyesen - kritizálva is azt, merthogy Marbe ezt az „egyöntetúséget” végső, másra vissza nem vezethető alapjelenségnek tartja”. L. dr. Hermann Alice 1963. Óvodás korú gyermekek tájékozottsága a világban. Tankönyvkiadó, 150. Forrása: Marbe, Karl: Über das Gedankenlesen und die Gleichförmigkeit des psychischen Geschehens. Zeitschrift f. Psychologie, 1910. 
A tanulmányban „nagy felbontásban”, ill. „mélységben” igyekszem bemutatni az azonosság- és különbségképzôdés mögött álló erók természetét és rétegzettségét, ezúttal nem törekedve arra, hogy az egyes állítások mögött kirajzolódó tudománytörténeti vonulatokat és a testvérfogalmakat is bevonjam az elemzésbe.

4. S végül: a hiányzó poszt-watson-cricki csoporttudat-elméletnek megfelelő fogalmi kerete lehet egy olyan teóriakezdemény, amely képes meghaladni a watson-cricki szint két korábban bemutatott nagy korlátját. Erról több alkalommal, de a teljesség igénye nélkül már korábban is értekeztem, így ez a tanulmány az információközösségról eddig általam írottak valamiféle kései bevezetésének is tekinthető. ${ }^{19}$

Mielőtt belekezdenék a négy hipotézis kibontásába, tisztelgő fóhajtással vissza kell térnem arra, hogy vajon miért egy poros tudósvitát megidézve, az „ócskaságboltból" választott kiindulópontok felól építem fel a mondanivalómat. Több mint tíz éve, a tajvani nemzeti egyetem könyvtárának alagsorában búvárkodva bukkantam McDougall könyvére, és elbúvölt annak a felismerése, hogy miért volt megoldhatatlan akkor a vita megnyugtató eldöntése, milyen fogalmak és ismeretek hiányoztak vitázó tudósainknál ahhoz, hogy a magukra kényszerített „ördögi körból” kitörjenek. De imponáló volt az érveknek az a feszes szerkezete is, amelyben elókerültek, s még ha minduntalan Maciver álláspontját is tartottam magamhoz közelebb állónak, a problématér analitikus tisztázásának vágyát sokkal erôsebbnek éreztem McDougallnél. Ahogy Elisabeth R. Valentine írja a pszichológia „mendeli korszakáról”: „elő́nye volt ennek a megközelítésnek, hogy a tudósok szabadon használhatták intuíciójukat, [...] (s így) minden felfogás hozzájárult valamennyire a pszichológia történetéhez". ${ }^{20}$ Bízom abban, hogy a csoporttudat mendeli paradigmájához való visszanyúlásnak is van értelme, $\mathrm{s}$ a hajdan volt tudósvita sem a megkésett eredményhirdetés miatt fontos, hanem azért, mert tartós inspirációforrás lehet a témakör sokkal teljesebb körüljárásakor.

\section{Egy fekete doboz felnyitása}

„.... TÁRSULÁS a természetben, minden életjelenség körében alapvetô. A TÁRSULÁSKÉPESSÉG (latinul sociabilitas) például a fákra is jellemző sajátosság, amely meghatározza a faj elő́fordulásának módját a növénytársulásban. A tudósok a TÁRSULÁSKÉPESSÉGET egy képzeletbeli skálán öt fokozatban értékelik. Az elsốnek az felel meg, ha a fa szálanként, az ötödiknek, ha tömegesen található. A közbülső három fokozat a kis csoport, a folt és a nagyobb telep. A fákról nem nehéz az emberi TÁRSULÁSra, a társadalomra gondolni..."

(Csízió, Liget, 1998. szeptember, 2.)

${ }^{19}$ Leginkább: Információközösségek. Kísérlet egy fogalom megragadására. In Mobilközösség - mobilmegismerés. 2002. Szerk.: Nyíri Kristóf. Budapest, MTA Filozófiai Kutatóintézete-Westel, 19-40. Továbbá: A világtársadalom mint információközösség. Norbert Wiener, az információ társadalomelméletének plebejus teoretikusa. In Neumann Jánostól az internetig. Akik nyomot hagytak a 20. sz.-on. 1999. Szerk.: Z. Karvalics László. Bp., Napvilág, 29-71., Információ versus (?) kommunikáció. 1995. Jel-kép, 2, 83-96. Megjelenés elốtt áll a „Tukán indiánok álmaikat mesélik. Az információközösségek kialakulása” c. tanulmányom.

${ }^{20}$ Valentine, u.o. 
Valószínúsíthetô, hogy Maciver és MacDougall emelkedett stílusban megformált fa-és erdóhasonlatai nem lesznek olyan közismertek és emlékezetesek, mint mondjuk a Toldi álomallegóriája, a szárnyaitól lépni nem tudó albatrosz fájdalmas, komplex szimbóluma vagy a már említett Ramón y Cajal merész hasonlata ${ }^{21}$ az egyetemes Tudomány fájáról, amelyen a tudósok mint hernyók végzik fáradságos munkájukat, a teljes lombozat átlátása nélkül. Talán még leginkább a „kollektív fa” mint „módszertani metafora” állíthatja maradandó és elgondolkodtató fogalmi próbatétel elé mindenkori olvasóját, de kétségkívül izgalmas kihívás a fák, a facsoportok és az erdók képi világával kerülni közelebb az emberi csoportok, a társadalom fogalmi és szerkezeti sajátosságaihoz.

Kézenfekvónek látszik, hogy az analógia kiterjesztésével ugyanebben a keretben érzékeltessük, mennyire egydimenziósak és elégtelenek a vitázó felek által felsorakoztatott érvek és magyarázatok. Az egykor volt tudósvita ezért inkább olyan szövegbúvárlatra ad módot, ahol továbbra is az erdővel és a fákkal kapcsolatos ismereteinket mozgósítva, de a hasonlatokat továbbépítve egy összetettebb, árnyaltabb leírás esélye csillan meg.

\section{Elsó szint}

Az a kiinduló állítás, hogy a csoport több (vagy más), mint az egyének összessége, alig több egyszerú tautológiánál. Nem feltételezhetố, hogy bárki (esetünkben például Maciver, ahogy McDougall sejteti) komolyan vitatná ezt. Az anyagi világ organizációjának banális ténye, hogy elkülönithetóen azonositható darabjai egyúttal és egyidejüleg nagyobb méretü alakzatok részei is. Az élettelen természetben könnyú végigjárni a „rendszerszintlétrát”, mondjuk a homokszemektól indulva a belólük felépülő homokbuckákon, majd a nagykiterjedésú dúnéken át a sivatagig. Az élő rendszerekkel már elkezd meggyúlni a bajunk, hiszen oly sokféleképpen tudnak szervezôdni. ${ }^{22}$ Gombát és gombatelepet látunk, de ezeknek a természetadta struktúrája nem olyan, mint az egyes virágé és a hímes rété: a mycélium által összekapcsolt gomba-lény másképp írható le, mint a független magocskákból kinövố virágszálakból összeálló sziromszônyeg. Vagy hogy a fánál maradjunk: a kutatóknak is nagy meglepetést okozott, amikor az egyik legósibb fafajtáról kiderült, hogy gyökereinél fogva összekapcsolt telepként létezik, és nem különálló fatörzsek ,,csoportosulása”. De vegyük a Dictyostelium nevú amóbát, amely kifejezetten társas lénynek tekinthetố (social amoeba), a gombákénál sokkal magasabb, már-már az állatokéra emlékeztetố genetikai diverzitással, specializált sejtekkel és a mérettốl remélhetô elónyök miatt folyamatos nyomással a további növekedésre.

Kétségtelen, hogy az élő rendszerek effajta „egyediség- és identitásszerkezete” evolúciós „behuzalozáson” alapul, és hosszú alkalmazkodási folyamat végeredménye-

${ }^{21}$ In Tưdományos kutatásra vezérlố kalauz. Ford. Lenhossék Mihály. Bp., Tudományos Könyvkiadó Vállalat, 54 .

${ }^{22}$ Ahogy McDougall is észreveszi: „párhuzamos nehézség mutatható ki az állati élet alacsonyabb rendú formáiban is. Ismeri-e vajon Mr. Maciver egy szivacs, egy úgynevezett „korallbogár” vagy a hólyagmedúza szervezetét? Tagadná-e egy emberi lény egységét, vagy elutasítaná-e a gondolatot, hogy ezen lénynek tudata van pusztán azért, mert ezekben az alacsonyabb rendú élólényekben az egység korlátait nehéz vagy lehetetlen meghatározni? 
ként jön létre. A magányos lét, a tényleges, sarjadzásszerú fizikai összekapcsoltság vagy az egyedek puszta aggregációja egyaránt sikeres stratégia lehet, mert a faj vagy a populáció így kialakuló ,architektúrájától” függetlenül a fajtársaknak nagyon sokfajta módja van arra, hogy a többi egyed túlélési esélyét (is) megnövelö mechanizmusokat hordozzanak, ill. aktualizáljanak.

Ettól azonban még nagyon sok olyan jellegzetesség, sajátosság és esetlegesség határozza meg a túlélést vagy a sikerességet, amelyek nem a szervezôdésnek ebból a (makro)struktúrájából következnek, és amelyeket sem az ad hoc csoportosulás, sem az állandó csoportlét nem magyaráz meg önmagában. Nagyon sok olyan egyedi, morfológiai, mikrokörnyezeti, topológiai és más attribútum ${ }^{23}$ jellemezheti egy adott populáció vagy élólénycsoport egyedeit, amelyek úgy múködnek „,klaszterképzóként”, hogy a lehetséges csoportosíthatóságuk alapjául szolgáló sajátosság csak bizonyos körülmények, élethelyzetek, szituációk fennállása esetén válik ,jelentéstelivé”, egy eseménysorozat lefutásának mikéntjét meghatározóvá.

A fákhoz Maciver felszólítására visszatérve („vizsgálhatjuk az egyes fában vagy fafajtákban nem felismerhető hasonló elemek természetét is"): klaszterképző lehet az, hogy egy levélkártevố, egy erdốtûz vagy egy földcsuszamlás mekkora területet fertốz meg vagy pusztít el; hogy mekkora súrúség jelent védelmet olyan madarak fészekrakásához, amelyek aztán a fát nyugtalanító élősködókból lakmároznak majd. A vízközelben nőttekhez képest nagyobb raktározási teljesítményre kell berendezkedniük a szárazabb talajban gyökeret vert fajtársaknak. Nagytestú növényevók csapásai mellett sokkal nagyobb a hajtások lerágásának veszélye. Az ilyen jellegú megoszlásokból adott típusú külsố feltételek, ill. változások esetén fakadhat evolúciós dinamika is, de az egyes fák sorsának alakulásától függetlenül akár évszázezredekig maradhat fenn a különbségeket elfedő erdőszintû́ stabilitás is.

Fontos látni, hogy ezek a megoszlások egymást sokszorosan átfedô attribútumhalmazokat hoznak létre, amelyeknek a jelentôsége egy változásegyüttes vagy eseménysor „miértjeinek” magyarázatakor válik drámaian egyértelmúvé. A csoporthoz tartozó egyedek megkülönböztetó sajátosságát ugyanis az adja, hogy léteznek olyan attribuitumegyiittállások, amelyek ki氵árólag óket jellemzik (miközben más attribútum-csoportok meglétében különbözó fajtársakkal különbözóképpen osztoznak). A nagy misztérium tehát az, hogy a csoport egészében meglevö attribútumkészletnek, mely egyedi kombinációjával válnak leirhatóvá és megérthetóvé az egyedszintü történések.

Ehhez képest pontosan fordítva ülünk a lovon: már a „viselkedés” alacsony fokán is mindenáron arra keresünk magyarázatot, hogy miként lehetne egy magasabb rendszerszint felól megmagyarázni az alacsonyabb rendszerszint valamely rejtélyesen komplex megnyilvánulását.

A parányi, fél milliméteres hidrafaló örvényféreg (Micrositoma) a hidrák bekebelezésével tesz szert szúrósejtekre, és ezeket bonyolult módon alakítja saját fegyverévé,

${ }^{23}$ Ezúttal nincs mód arra, hogy elvégezzük az attribútumvilág mélyebb, nagyobb felbontású elemzését, vagy hogy az ugyanezt a jelenséget más fogalmi apparátussal tárgyaló elméleteket tegyük tudománytörténeti mérlegre. Egyedül annyit emelünk ki, hogy az attribútumok egyik csoportja magához az egyedhez kötôdik (struktúrájának, életfolyamatainak, adott életszakaszának vagy morfológiai sajátosságainak köszönhetôen), a másik csoport pedig a közvetlen környezet valamely (sokszor esetleges) állapot-jellemzôjébó1 származtatható. 
ún. „vándorsejtek” segítségével juttatva el a célállomásra, a bőrbe. Amikor azonban megfelelő (sejt)koncentrációban elég „lövedéke” van, akkor nem fogyaszt hidrát, még ha éhen is pusztul. A koordinációnak ez a sokszoros tökéletessége indította W. A. Kepnert arra, hogy már ezen a rendszerszinten is ,,csoportlelket” feltételezzen a sejtközi munkamegosztás háttereként. ${ }^{24}$

Vehetjük példának az amerikai vaddohányt, ezt a lágyszárú növényt is, amely látszatra tehetetlen elszenvedóje a kártevốk támadásainak, valójában azonban „úgy védekezik a leveleit rágcsáló hernyók ellen, hogy [...] különleges illatanyagokkal [...] segítségül hívja a kártevő ellenségeit, a hernyót pusztító parazitákat”. ${ }^{25}$ „A veszélyt jelzó illatanyagokat azonban más növényegyedek is érzékelik (sốt egyes kutatások szerint más növényfajok egyedei is készenlétbe helyezik védekezô mechanizmusukat, ha megérzik a levegóben, hogy a környéken baj van). A sejtszintú riasztás az ố szervezetükben is megindul", és sokkal gyorsabban tudnak majd reagálni, ha a kártevố rajtuk is megjelenik. Erre az összehangolt védekezésre az elemzốk már afféle „tudatosságként” tekintenek, de vajon van-e szükségünk új magyarázó elvre, hogy modellezzük a vaddohány viselkedését?

Az örvényféreg sejtjeinek munkamegosztása és autonóm múködése tökéletesen levezethetô „csoportlélek” tételezése nélkül is, az egyes örvényférgekben ugyanazon mechanizmusok alapján mennek végbe a folyamatok, amelyek végén a szúrósejtek (nematociszták) geometriailag egyenletesen oszlanak el a testfelszínen.

A vaddohánynál a hernyó nyála és a rágásmintázat indít el egy kémiai reakciósorozatot: elsóként egy sebhormon kiválasztását, majd az illatanyag termelésének megkezdését, végül az illat kibocsátását. Evvel párhuzamosan a megtámadott növény megkezdi bizonyos génjeinek az átprogramozását, hogy képes legyen egy olyan fehérje előállítására, amely méreganyagként okoz zavart a hernyók emésztésében.

Az egész folyamatot értelmezó átfogó elvek bevezetésére itt sincs szükség, mert akárcsak az örvényféreg esetében - minden részfolyamat önmagában jól magyarázható, levezethetô, s csupán azért érzünk hiányt a megismerésben, mert (egyelóre) nem vagyunk képesek rekonstruálni azt a történeti utat, amelynek során az egyes részképességekból szép lassan felépült az összetettnek mondható viselkedés.

Az erdóvel, a fákkal és a vaddohánnyal a dolgok „megtörténnek”, még akkor is, ha az egyedek a környezettel folyamatos interakcióban vannak, és életjelenségeik révén valamiképpen befolyásolják ezen folyamatok egy részét. Ami történik, abban nincs helye alternatív forgatókönyveknek, az események ,akció-reakció” lefutásúak. A történések különbsége az egyedeket jellemzó attributum-együttállások kïlönbségéból fakad. Innen nézve az evolúciós hajtóeróként múködô szelekció leírható a környezeti kihívásokkal szemben sikeresnek bizonyuló együttállások minél teljesebb, populáció- vagy fajszintú elterjedésére irányuló nyomásként is, ahol az individuális sikeresség alapjául szolgáló egyedi

\footnotetext{
${ }^{24}$ Karl Lashley: Az ösztönös viselkedés kísérleti elemzése In Alaklélektan. 1974. Vál. és szerk. Kardos Lajos. Budapest, Gondolat Könyvkiadó, 278-279. Lashley tanulmánya Kepner 1925-ös írására hivatkozik, amelynek feloldását nem tartalmazza a kötet. Kepner maga 1911 és 1951 között tanulmányok tucatjait írta kedves microstomáiról.

${ }^{25}$ Szekeres Júlia: Növényi segélykiáltás. 2007. Népszabadság, december 8. http://www.nol.hu/cikk/474225/ Minden, a vaddohánnyal kapcsolatos leírás kisebb változtatásokkal a cikk eredeti fordulatait használja.
} 
attribútumkombináció hosszú távon csoportszintü jellegæetességgé, tipikus (fajspecifikus) tulajdonsággá válik. Belátható, hogy ezáltal meg is szűnik attribútumkombinációnak lenni, az evolúció belsốvé teszi, „interiorizálja” az alkalmazkodást, s mindezt a genom szintjén: a folyamatot teljes joggal nevezi Csányi Vilmos (másokkal együtt) „genetikai megismerésnek". ${ }^{26}$

\section{Második szint}

Ez az alapképlet akkor kezd bonyolultabbá válni, amikor a magasabb rendú élólények esetében az attribútum-együttállásokból fakadó különbségeken túl márviselkedéskïlönbségek is megjelennek, amelyekben számos új, evolúciós fejleményként kialakuló jellegzetesség a ludas. Ezek egyidejúleg, egycsapásra és egymástól elválaszthatatlanul jelennek meg mint a genetikai megismerés eredményei, és a differenciálódás egy adott pontján új minőségbe forrnak össze.

Evvel az új minőséggel születik meg az élő rendszerekben az információkezelés képessége, amely egyidejúleg feltételez több teljesen specializálódott testrészt: ezek közül legalább egy a környezet valamely jelentésteli változásának érzékelésére képes (érzékszerv); egy másiknak döntést hozó (cselekvésutasítást kiadó), „,vezérlô” funkciója van (a majdani agy, ill. az idegrendszer korai változataként), a harmadik az elkerülő viselkedéshez szükséges helyváltoztató mozgást (lokomóciót) teszi lehetővé. A cselekvés mindezekkel szorosan összekapcsolódó intencionalitása annak az eredménye, hogy a test összetettsége miatt itt már az egyre bonyolultabb „belvilágból” származó ingerek is megjelennek, ${ }^{27}$ és keverednek a külvilágból származókkal. Sót, a korábbi akció-reakció típusú automatikus „lefutásoknak” feltehetôen éppen a belső (interoceptív) és a külső (exteroceptí) „pályák” kereszteződési pontjaiból kialakuló idegrendszeri központban végbemenố kapcsolások feltételessége vet véget. A tengeri zsákállatnak (Ascidia) ebihalkorában van szeme, agya és velő́csöve, amelyek a tájékozódást és a mozgásvezérlést szabályozzák. Ahogy azonban az idôsebb egyed felhagy a mozgásra épülố életmóddal, és egy kiválasztott sziklához tapad, hogy élete végéig planktonokat szúrjön ki a vízból, úgy válik szükségtelenné számára a bonyolult idegi apparátus. Egészen különös dolog történik: a zsákállat „feléli”, visszafejleszti, „elfogyasztja” saját szemét, agyát és velőcsövét, és „visszaáll” egy vegetatív állapotra, amelyben már csak a szájnak és a gyomornak van jelentôsége. ${ }^{28}$

A „két világ határán” mozgó zsákállat jól példázza, ahogyan egyidejúleg és egymástól elválaszthatatlanul születik meg a cselekvéskoordinációt a külvilág felé „,behuzalozó" mechanizmus és a test önmagára vonatkozásának mozzanata, amelyet késóbb

${ }^{26}$ A genetikai megismeréssel bizonyos analógiába állítható a Jung-féle ,kollektív tudatalatti”. Az ezt alkotó ösztönök és „archetípusok”, csoportsajátosságok, hosszú idő alatt alakulnak ki, s noha feldolgozásuk nem tudatosan történik, mégiscsak hatnak a viselkedésre és a választásokra. Ha a kollektív tudatalattit is tudattartalomnak tekintjük, feloldható a tipológiákban.

${ }^{27}$ Hogy csak a két legfontosabbat említsük: az emésztốrendszerból és a mozgásszervektốl érkezô (proprioceptív) információt.

${ }^{28}$ Susan Greenficld 1997. Megmagyarázzuk az emberi értelmet. Kalauz az emberi test vezérló központjához. Magyar Könyvklub-Helikon, 13. 
lelki (pszichikus) oldalként látunk viszont, annál tisztábban és egyértelmúbben, minél fejlettebb lénynél vizsgáljuk.

Nem véletlen, hogy időtálló (és még mindig nem valódi értékén kezelt) monográfiájában ${ }^{29}$ Kardos Lajos ezt a kettôsséget képzi le a „neuropszichikus információ” kategóriájával, részletesen rekonstruálva, hogy miként jelenik meg az információs múködésmódot lehetôvé tévő képességegyüttes az állatvilágban. ${ }^{30}$

Mindaddig azonban, amíg nem jön létre az információ tárolásának képessége, a viselkedés is programozott, hiszen a döntési pályák - az érzékszervektól és az idegrendszertól függetlenül - elóformáltak. Az egyedek viselkedése azonos helyzetekben azonosan alakul, és ha mégis különbséget találunk, akkor annak oka nem a még kezdetleges neuronhálózat múködési sajátosságaira, hanem valamilyen egyedi attribútumkombináció meglétére vezethetô vissza.

A memória mechanizmusainak kialakulása azonban mindent megváltoztat. Azzal, ahogyan az egyedi döntést befolyásoló mintázatok között megjelenik olyan is, amely a „pillanatnyilag adott ingerkörnyezeten” túl hordoz jelentést, ${ }^{31}$ a cselekvést meghatározó tényezók új családja születik meg. Az egyedi történéseket hordozó egyedi tapasztalatok „elóhívhatók" az emlékezeti tárból, amikor csak szükség van rájuk, és ettól a változatosságnak egy új rendszerszintje épül a korábbi attribútumkombinációs szint fölé: $a \approx$ individuális tudattartalmaké. S mivel ezek a „lehetséges tudattartalmak” nagyjából azonos készletéból aktualizálódhatnak, szinte pontosan ugyanaz igaz rájuk, mint az attribútumokra: lehetnek maradéktalanul elterjedtek csoportszinten, az attribútumkülönbségekre ráépülő tevékenység- és érzékeléskülönbségek miatt lehetnek csak néhány csoporttag memóriájában, s lehetnek akár kizárólag egyetlen individuum elméjében is. Mármost avval, hogy sokakban van ugyanolyan tudattartalom, megjelenik egy vadonatúj csoportképzó elem. Az azonos információt (vagy információk azonos kombinációját) használók azonos élethelyzetben azonos viselkedést produkálnak, de a viselkedéskülönbségek mögött sok esetben már a memóriatartalmak különbsége áll.

A menomini indiánok között végzett kutatások kimutatták, hogy a törzs tagjai mintegy 70 százalékának azonosak a személyiségvonásaik. „Olyanok, mint a futószalagon készült szellemi kópiák - mondja Gorbovszkij. ${ }^{32}$ - A törzs minden tagját ugyanaz az információ, ugyanazok az események, ugyanazok a gondolatok alakítják." A csoportképzốdés alapja a tapasztalatok közössége. Erôs automatizmusok munkálnak, amelyek a tapasztalatok megosztására hatnak, ám az idốtengely mentén (az életkor elörehaladásával) az individuálisan szerzett és a közösség többi tagjával meg nem osztott információk száma egyre nő, így mind nagyobb a matematikai esély egyedi tapasztalatkombinációra. A munkamegosztás korai formái hasonlóképpen kedveznek az eltérő észlelési helyzetekból és tapasztalatokból összeadódó különbségeknek - ekkor azonban már javában múködik egy még újabb mechanizmus is.

\footnotetext{
${ }^{29}$ A neuropszichikus információ eredete. 1976. Budapest, Akadémiai Kiadó.

${ }^{30}$ Kardos (és vele teljesen megegyezô módon Derek Bickerton is) a tengeri rózsával (Stomphia coccinea) példázza, miként lesz függvénye a viselkedés az információnak. Kardos; u.o. 131. és Derek Bickerton 2004. Nyelv és evolúció. Bp., Gondolat, 90.

${ }^{31}$ Kardos Lajos 1988. Az állati emlékezet. Budapest, Akadémiai Kiadó.

${ }^{32}$ Gorbovszkij, Alekszandr 1983. 2000-ben és azután. Bp., Kozmosz.
} 


\section{Harmadik szint}

A csoportképzôdés új szintje jelenik meg, amikor lehetôvé válik az individuális tudattartalmak közösségi megosztása, és intézményesedik a jelentéscsere. Ez kizárólag a Homo nemzetséghez kötôdik, a nagyon fejlett, késói Homo Erectusra talán, a neandervölgyi emberre már szinte bizonyosan igaz. ${ }^{33}$

Ne feledjük: nagyon magas szintú tevékenységkoordináció érhetô el a csoportban már az individuális információk közössége révén is anélkül, hogy ez valamiféle „megosztásban” nyilvánulna meg. ${ }^{34}$ A nyelv, a kommunikáció és a kultúra azonban az információk cseréjének köszönhetốen erốs akkumulációs nyomást testesít meg, és a genetikai megismerésnél sokkal gyorsabb alkalmazkodási stratégiát tesz lehetôvé.

A kulturális mintázatokra is igaz azonban, hogy hordozóik individuumok, még akkor is, ha a jelentések, normák, szabályok, viselkedésminták és elóírások más individuumok közvetítésével vagy kollektív események (szertartások, rítusok, törvénynapok, ünnepek stb.) alkalmából konstituálódnak. Minél összetettebb, gazdagabb egy kultúra, annál nagyobb a kódok változatossága, és az adott kultúrát hordozó (újratermelő) közösség egyes tagjai egyre kevésbé tudják a teljes kulturális készlet valamennyi elemét hordozni. Így áll elő az attribútumkombinációkra emlékeztetố csoportképzôdési alaphelyzet, hogy ti. az egyes kultúraelem-kombinációk birtoklásában meglévő különbségek értelmeznek viselkedésbeli különbségeket, a kulturális kódok azonosságából pedig azonos körülmények között azonos viselkedés fakad. Ezt csak felerôsíti az a tény, hogy a kulturális kódok nagy része közvetlenül vagy közvetve kifejezetten magát a viselkedést szabályozza, a kód elfogadása egyenlố az annak megfelelő (helyes) cselekvéssel.

Viszonylag könnyen belátható, hogy a demográfiai gyarapodás öngerjesztő folyamatokat indít be. A nagyobb létszámú közösségek létrejötte hatványozottan növeli meg az attribútumkombinációk számát, az így kialakuló változatosság pedig jó táptalaja a kulturális innovációnak, és elősegíti a megismerés újabb és újabb teraszaira való eljutást. Ez ismét csak az attribútumkombinációkat szaporítja, és így tovább, hacsak a folyamat le nem lassul valamely egyensúlyi állapot közelében (ahol a környezeti stabilitás

\footnotetext{
${ }^{33}$ Néhány kutató szerint az erôsen szociális és szoros szülő-utód kapcsolatban élő állatoknál valóságosan és nem szimbolikusan kell „tanításként” felfogni azt, ahogyan az idôsebb egyed a fiatalabbal tréningszerúen valamilyen cselekvést „,csiszolgat”, és ez már a tudattartalom megosztásának a „, harmadik szintjéhez” sorolandó. Evvel szemben itt még csak nem is az egyéni tapasztalatok „második szintư” átadása zajlik, hanem valójában mindkét oldalon (a „tanító” és a „diák” felól nézve is) programozott viselkedés-kondicionálás történik, tehát sokkal inkább az „elsô szinthez” tartozó tevékenységnek kell tekintenünk.

${ }^{34} \mathrm{Az}$ oroszlánok például jól összehangolt csapattevékenység keretében vadásznak: a ragadozók automatikusan helyezkednek el (a prédállathoz képest egy hátul, egy elöl, a többi oldalt), minden egyed ugyanúgy „képzeli el” a saját szerepét, és ebben a forgatókönyvben játssza azt el. Sốt, megfigyelók szerint vannak „kedvenc szerepek” és „kedvenc párok”, vagyis az oroszlánok nemcsak „személyesen ismerik egymást”, de van elképzelésük arról is, hogy mit „szeret” vagy „szokott” csinálni a másik. A jelentéscsere hiányát azonban jól tükrözi az a tény, hogy a préda fajának (zebra, bivaly vagy egyéb állat) kiválasztása ,hagyományon” alapul (elsősorban azon a tapasztalaton, hogy melyikból van több, melyikhez könyebb hozzájutni). Ha viszont a szokás már kialakult, egy ideig fönnmarad még akkor is, ha idóközben a prédapopuláció létszáma jelentôsen lecsökken. Csak egy idô elteltével váltanak a ritkábbá váló zsákmányról a gyakoribbra, ami bizonyára sokkal gyorsabban történne meg, ha az állatoknak módjukban állna individuális tapasztalataikat és megfigyeléseiket „összegezni”. L. Fekete Zita 1995 nyár. Az állatok királya. Süni és a Természet.
} 
erôsödése révén csökken az innovációs nyomás, és a populáció létszáma többé-kevésbé állandóvá válik), vagy ha az adott közösség nem zuhan népességfogyási örvénybe.

Azt se felejtsük el, hogy a kulturális kódok világa sokszorosan rétegzett. Piramisa a hétköznapi érintkezés banális és elemi konvencióitól (pl. köszönés) a világképig vagy a vallásig, a szuperkomplex tartalmakig terjed. Az attribútum-kombinációkat szakadatlanul termelő különbségek így nem homogén, hanem sokszorosan tagolt térból táplálkoznak. Ennek a jelentôsége akkor válik nyilvánvalóvá, amikor egy nagyon összetett kulturális mintázat (pl. egy tételes vallás) valamelyik, látszatra vagy valóságosan is alacsony szintû elemében van különbség két csoporttag felfogása (vagy két elterjedt értelmezés) között, mert már ebben az esetben is két különböző mintázatról beszélhetünk! A mindössze egy „jottányi” különbség a „homo usion” és a „,homo iusion” olvasatok között csak látszatra alacsony szintú eltérés, valójában alapvető és sarkalatos a teljes mintázat szempontjából, és minden esetben végbemegy a valóságos elkülönülés, amikor a mégoly kis különbségnek mégis jelentôsége van (másképpen fogalmazva: valamilyen kontextusban jelentésteli). A vallástörténelem nagyszerúen illusztrálja ezt a dinamikát, amelynek aktuális „lenyomata” a vallások „családfája”. De nagyon hasonló a differenciálódás logikája a nyelvek esetében is, ahol a nyelvközösségek felszíne alatt nagyon sokáig megférnek az egyes beszélóközösségek egymást nyelvhasználati változatokkal sokszorosan átfedő csoportjai, hogy aztán egy adott pillanatban már új, elkülönült nyelvekról beszéljünk.

Minél magasabb pontot figyelünk a kulturális kódok piramisán, annál egyértelmúbbnek, annál kevésbé megkérdôjelezhetônek látszik a mintázatkülönbségek meghatározó szerepe. Minél lejjebb ereszkedünk, annál lényegtelenebbnek tû́nnek az egyedi mintázatkülönbségek - a magas szintú kódok felól nézve. Csakhogy az életjelenségek nagy részére igaz, hogy nem a legmagasabb szintû, összetett mintázatok vezérlik, s a kultúra egyúttal szakadatlan törekvés éppen arra, hogy a helyes és autentikus cselekvésutasításhoz ne kelljen „magasra” utazni a piramison. Ennek okán számtalan helyzetben válnak jelentéstelivé alacsony szintú kulturális kódok, és az ezekból fakadó viselkedéskülönbségek egészen eltérő forgatókönyveket eredményeznek. Ahol például a társadalmi különbségek reprezentációjának nagy fontosságú eszköze a megszólításokban leképeződő bonyolult hierarchia, ott egy egész karriert, egy egész sorsot tehet tönkre egy rosszul megválasztott megszólítás. Emberi kapcsolatok futnak zátonyra, amikor egyetlen szállóige eltéró értelmezése miatt elillan a kapcsolati teret szabályozó legfontosabb instancia, a bizalom. Érzékenynek kell tehát lennünk az alacsony szintú különbségekre is, miközben ráadásul „felfelé” is tovább épül a rendszer: a kulturális kódoknak létezik egy speciális fajtája, amely a csoporttudat szempontjából megkülönböztetett jelentôségú.

\section{Negyedik szint}

A csoporthoz való tartozás felismeréséból, tudatosításából, a közösség reflektálásából születik a csoportidentitás. Elterjedt felfogás szerint a „másokkal” szemben kiformált mitudattal kezdődik, s a közösség méretének növekedése, a munkamegosztás és a társadalmi egyenlő́tlenségek révén kezd többdimenzióssá válni. Az egy- 
mást átfedô csoportidentitásokból, a kulturális kódokból és a személyes tapasztalatalatokból összegyúrva áll elő az egyént mindenki mástól megkülönbôztető személyes identitás.

A csoportidentitás elófeltétele a „csoport” fogalma, a „csoportmivolt” felismerése és a felismert csoport karakterizálására való képesség. Az azonosulás mellérendelése, a valódi csoportidentitás kialakulása akkor történik meg, amikor a fogalmi gondolkodás és a kultúra differenciálódása elér egy ehhez szükséges fokot.

Csoportidentitást teremthet a fizikai attribútumok közössége („,mi, feketék”, „mi, nók”, „mi, kövérek” stb.). Sok esetben a közösség reprezentálása is fizikai attribútumokkal történik, amelyek így jelértékúivé válnak, és az összetartozást szimbolizálják (a Kossuth-szakáll mint a lappangó „ellenállással” való szolidaritás kifejezése a Bach-korszakban, a kopaszra borotvált fej mint a skinheadkultúrához való tartozás jelképe, speciális hajviselet egyes rockzenei szubkultúrákban).

Csoportidentitás születik az egyéni tapasztalatok során, a cselekvés (vagy történés) közösségreflexiójaként. Egy adott buszjárat utasai látszatra esetleges, alkalmi csoportosulást alkotnak, de sokféleképpen válhat jelentéstelivé, reflektálttá és ezen keresztül identitásképzôvé akár ez is. Elég hozzá a rendszeres ismétlődés („,mi vagyunk a hat huszas busz utasai, reggel egyszerre indulunk munkába, és hónapról hónapra egymás arcát látjuk”), egy közös, rendkívüli élmény („mi vagyunk a buszbaleset túlélói”) vagy szinte bármilyen közös élmény („mi nem tettünk semmit, amikor ruhaviselete miatt bántalmazták azt a fiatalembert hátul”). Az azonos munkát végző, az azonos hobbit múvelố vagy az azonos sportot úzố személyek identitásközösségének esernyốje alatt bôven elfér a tapasztalatközösségból kinövố információközösség és annak csalhatatlan jele, a viselkedés azonossága tipikus helyzetekben.

Csoportindentitásokat épít fel a kultúra is. A vallási közösséghez való absztrakt „besorolás” mellé a szúkebb gyülekezethez való tartozás tapasztalatai illesztenek új identitásréteget. Ezt a vertikálisan tagolt társadalmakban átfedi a vagyoni vagy osztálykategóriák szerint elkülönüló csoportokhoz való tartozás tudata. Csoportidentitásokat termelnek a kulturális fogyasztás típusai, a politikai hovatartozás (párt)preferenciái. Azok a tömegjelenségek (a sztrájkoló munkástömegek, a tüntetók, az oszlopban masírozó, menetdalokat éneklő paramilitáris csapatok fellépései), amelyekre a csoporttudat korai irodalma igyekezett megfeleló magyarázatot adni, tipikusan egy magas szintú kulturális kód, az ideológia által vezérelt csoportképződés termékei.

Paradox módon csoportidentitás-képző maga a csoportidentitás is. A WASP rövidítés (White Anglo-Saxon Protestant) a fehér angolszász protestáns közösséghez tartozó amerikai állampolgárok afféle „szuperidentitását” fejezi ki: az identitáselemekból összeálló kombináció úgy viselkedik, mint egy önálló, homogén csoportidentitás.

\section{Bonyodalmak a csoportba tartozással}

Az eddig bemutatott négy csoportképződési szint olyan absztrakció, amely az analitikus társadalomkutató eszköze ahhoz, hogy elkülöníthetô jelenségcsoportokat leírjon és jellemezzen. A ,besorolások” nagyobbrészt külső́dlegesek, egyáltalán nem szükség- 
szerű, hogy az érintettek tudatában legyenek az ekképpen előálló csoportokba való tartozásuknak.

Az individuumok gyakran nincsenek tisztában vele, hogy milyen megkülönböztetố (és ezen keresztuil csoportképzố) fizikai attribútumaik vannak. A harántsüllyedés olyan ízületi deformáció, amelyet a lábfej tulajdonosa túlnyomórészt nem is tudatosít, de „járása” valamennyire mégis visszatükrözi ezt az adottságát, és a „különböző járástípusok" észlelésekor ez a megfigyelő számára manifesztálódhat. A bớrszín fekete mivolta egészen addig „természetadta” tulajdonság, és nem „lehetséges attribútum”, amíg ki nem derül, hogy létezik ,nem fekete” is. Így eredményez a közösségek összekapcsolódásából fakadó értelmezési-feldolgozási kényszer és az emberekre vonatkozó megismerési univerzum kitágulása bonyolultabb identitásszerkezetet is.

Ugyanez igaz az összes többi szintre is. A személyes tapasztalat az izoláció miatt nem vethetố közvetlenül össze mások személyes tapasztalataival. Egészen addig, amíg jelentéscserére (vagy ritkábban: az analógiás gondolkodás révén mintázatazonosság-felismerésre) nem kerül sor, a tapasztalatok azonosságából nyert információk azonossága nem feltétlenül tudatosul.

Az alternatív minták ismeretének hiányában egy kulturális kód megléte ugyanúgy „természetadta állapot”, mint egy fizikai tulajdonságé. A (kényszer)szocializációs minták egészen addig nélkülözik a reflexiót, amíg az így közvetített tartalom nem kerül ellentétbe a valóság valamely darabkájával (és így hatékonysága, autenticitása megkérdôjelezốdik). Nem véletlen, hogy tekintélyelvư társadalmakban az alternatív minták megjelenésének megakadályozása, az exogén információs gát ugyanúgy része a kánonnak, mint a norma belsố megkérdójelezésének tiltása, az endogén információs gát. A kételkedés tilalma az iszlámban vagy a félelem légköre az autokráciákban a reflexió ellen ható technika.

A fentiekhez hasonlóan egyáltalán nem szükségszerú, hogy (fel)ismert legyen a lehetséges identitásközösség alapjául szolgáló jellegzetesség, és nem feltétlenül szükséges annak a tudatosulása sem, hogy ez a jellegzetesség akár csoportképző is lehet. A latens homoszexualitást sokszor hamarabb észleli a külvilág, mint maga az egyén. Extrém tárgyak gyújtőinek sorsfordító élménye, amikor kiderül, hogy van még legalább egy valaki, aki pontosan azt gyújti, amit ók.

Az információk azonosságán alapuló közösség akkor is fennáll tehát, ha a csoporttagok nincsenek tudatában annak, hogy mások is rendelkeznek ugyanazzal az információval, mint ớk. Sót, az sem szükséges, hogy magukról a „másokról” egyáltalán tudomásuk legyen, hiszen az információk közössége megvalósul enélkül is.

Annak, amikor csak a face-to-face közösségeket tekintették közösségnek, régen lejárt az ideje. Benedict Anderson nemcsak a nacionalizmuskutatás úttörôje, hanem annak nagyszerú dokumentálója is, hogy egyetlen kulturális konstrukció, a nemzet fogalma miképpen válik gondolkodásformáló, cselekvésre késztetố és - ezeken keresztiul valóságalakító erôvé. ${ }^{35}$ A nemzethez való tartozás tudata akkor is eleven csoportképzó, ha az identitásközösség nagyobb része személyében teljesen ismeretlen. De ugyanez igaz alacsonyabb szintû́ kategóriákra is: egy labdarúgóklub (ma már határokon átnyúló) rajongói vagy egy író, egy fimrendezố „hívei” az elméjükben levő mintázatok közössé-

\footnotetext{
${ }^{35}$ Imagined Communities: Reflections on the Origin and Spread of Nationalism. 1983, 1991, 2006. London, Verso. Magyarul Elképzelt közösségek. 2006. L'Harmattan.
} 
ge okán csoportot alkotnak, és mindebból következóen azonos cselekvéseket hajtanak végre (pl. elmennek szurkolni a meccsre, megvásárolják kedvenc írójuk új könyvét, vagy jegyet váltanak a rendezó legújabb filmjére).

Nem szükséges az sem, hogy cselekvésben manifesztálódjon az információközösség. Ami aktuálisan vezérel egy döntést vagy cselekvést, az potenciálisan, mintázat formájában már elótte is jelen kell, hogy legyen az agyban.

Természetesen ott van az egymást metszó információközösségnek különös szerepe, ahol tevékenységszintú kapcsolatok, közvetlen interakciók befolyásolják a résztvevók viselkedési valószínúségét. A tanulási folyamat ilyenkor gyors, a közös cselekvési térben szerzett közös tapasztalatok formálta információközösségek akciós kimenetei látszatra programozottak. Valójában azonban ilyenkor is megmarad az individuális tudattartalmak szerepe, hiszen bármely információ bármely helyzetben jelentéstelivé válhat bármely cselekvés meghatározásakor, és alternatív kimeneteket eredményezhet. Sốt, a különbözố szintekról származó információk között szakadatlanul zajlik a rekombináció, az új és új mintázatok képzốdése, ami nagyban befolyásolja, hogy egy adott szituációban milyen viselkedés „hívódik elô”.

\section{További bonyodalmak: a négy szint egymást befolyásolja}

Tengiz Abuladze „Könyörgés” címú filmjének elsố etứdjében a hốs, Zvidaúri megvív a rivális kaukázusi hegyi közösség legjobb vitézével, és egy irtózatos, gyötrelmes küzdelemben végül is győztesen marad felül. Arra azonban, hogy a kulturális kódnak, népe törvényének és a párviadalokat kölcsönösen szabályozó kódexnek megfelelốen a fejét vegye legyốzött ellenfelének, már nem hajlandó. A személyes tapasztalat hullámfürdôjében ugyanis olyan mennyiségú információt szerzett ellenfeléról, hogy - akár a normasértés árán is - vállalja, hogy alternatívan cselekszik. Valahogy így gondolkozhat: „A másik vitéz nagyon hasonló volt hozzám, akár én is holtan maradhattam volna itt. Mennyire egyfajták vagyunk mi, még ha más is a nyelvünk, más a kultúránk, és más közösségért szálltunk csatába. Identitásközösséget érzek vele, nem veszem fejét. Tisztelem és tisztességgel eltemetem."

A normasértés, ahogy ebben az esetben is, mindig az individuális tudattartalom-kombinációk gyoozelme a kulturális kódok felett. Csakhogy számos esetben éppen a kulturális kód bizonyul erôsebbnek, és akkor még ott a másik két szint is. Mielốtt részletesen megvizsgálnánk a tipikus kölcsönhatásokat, foglaljuk össze és jelenítsük meg egyetlen táblázatban az eddig bemutatott négy szintet!

\begin{tabular}{||l|l|}
\hline 4. szint & Reflektív csoportfogalmak (identitás) és azok kombinációi \\
\hline 3. szint & Kulturális kódok és tartalmak kombinációi \\
\hline 2. szint & Individuális tudattartalom-kombinációk \\
\hline 1. szint & Fizikai attribútumkombinációk \\
\hline
\end{tabular}

Az elsốtôl a negyedik szint felé való mozgás bizonyos fejlődéstörténeti utat is reprezentál, de szó sincs róla, hogy mindez egyúttal hierarchiát is jelentene. Amikor ugyanis az agy a cselekvés sodrában mintegy „választ” a rendelkezésére álló készletból, ha- 
bozás nélkül nyúl a megoldás legjobb esélyét kínáló információdarabokhoz. Ennek megfelelően az egyes szintek információs mintázatai elképesztô változatossággal „írják felül” és befolyásolják egymást, ill. olvadnak össze kevert mintázatokká. Nem igaz tehát rájuk az a szép magyarázó modell sem, amellyel Vigotszkij oly virtuóz módon ragadta meg a magasabb pszichikus funkciók kialakulásának természetét, hogy tudniillik a kialakuló komplex formák mintegy maguk alá gyứrik, elhomályosítják az idóben korábbiakat és kezdetlegesebbeket. Itt ugyanis mindez fordítva is megtörténhet.

Már bizonyos patkánykisérletek is jól érzékeltetik, miként fakad a fizikai attribútumok különbözóségéból eltéró tapasztalat (a vitaminhiányos egyedek elónyben részesítenek mindenfajta új táplálékot, mérgezés esetén viszont képesek társítani az adott táplálék izéhez a veszélyt, még akkor is, ha csak egy nap múlva következik be a betegség). Csakhogy a fajtársaktól szerzett információknak sokszor olyan meghatározó szerepük van, hogy többek között képesek felïlírni az egyéni tapasztalatot (elsősorban az averziócsökkentési helyzetekben). ${ }^{36}$

Az érzékelést és az annak eredményeként megszületố információk minemúségét látszatra a fizikai attribútumok határozzák meg, és ahogy korábban láttuk, a tapasztalat azonosságából elvileg azonos információnak is kellene születnie. Ahogy Edward T. Hall ${ }^{37}$ írja: „Sokáig hittük, hogy a közvetlen tapasztalás minden ember közös élménye... Az ember és a tapasztalás viszonyára vonatkozó implicit (és nem egyszer explicit) hiedelmünket arra a feltételezésre alapoztuk, hogy ha két emberi lény ugyanazt a tényt »tapasztalja «, gyakorlatilag azonos adatok táplálódnak be központi idegrendszerükbe, és agyuk ugyanazt a képzetet regisztrálja. A proxemikai kutatások eredményei kétségbe vonják a fenti feltételezés helyességét. [...] A különböző kultúrákhoz tartozó emberek nemcsak különbözố nyelvet beszélnek, hanem [...] magát a világot is más-más módon érzékelik." (Kiemelés ZKL.)

De az érzékletek és tapasztalatok különbsége a fizikai attributumok különbségéból is származhat. Látáskárosodottaknak olyan érzékei is kifinomodnak, amelyek révén az „átlagos” emberekhez képest mást és másképp (is) fognak fel a külvilágból. (Különös, hogy ezt a kulturális kód is „kihasználja”: egyes népcsoportok szándékosan „elốidézik a különbséget”, pl. megvakítják a közösség egyes tagjait, hogy így tehessenek szert a csoport szintjén eltérő egyéni tapasztalatokra.)

A 17. században egy beszédszervi rendellenességgel született irokéz nem vehetett részt törzse amúgy nagyon demokratikusan szervezett tanácsülésein, mert ott csak azok ülhettek, akik képesek voltak álláspontjukat érthetốen, ékesszólóan bemutatni. Fizikai eltérése azonnal kizárta bizonyos társas történések megtapasztalásából, ebból fakadóan kevesebb kulturális kódra tett szert, mint társai, és mindezek végül ilyen divergens identitás kifejlődéséhez is vezethettek: „Irokéz vagyok, de nem tartozom a törzs teljes jogú tagjai közé."

Egy erốs individuális enteroceptív inger (pl. az éhségérzet) képes arra, hogy egy adott szituációban a kulturális kódokat (pl. a törvény betújét vagy a kisközösségek mindennapjait szabályozó konvenciókat) felülíró módon döntse el a cselekvés-kimenetet. (Ugyanerre képes annak a puszta tudata is, hogy más éhezók számára kell élelmet sze-

\footnotetext{
${ }^{36}$ Bilkó Ágnes: Táplálkozási szokások kialakulása az állatvilágban. 1993. Természet Világn, 3.

${ }^{37}$ Rejtett dimenziók. 1980. Bp., Gondolat, 24-25.
} 
rezni. $)^{38}$ De ugyanezt megteszi az identitásszint is. Az amerikai Emory Egyetem kutatóinak 2004-ben közzétett eredményei szerint a rendíthetetlen párthívek számára önjutalmazó hatású, ha a kedvelt politikust sikerül „megvédeni” azzal, hogy egy nyilvánvaló és félreérthetetlen tévedését valahogyan „kimagyarázzák” - az identitás és annak megerôsítése fontosabbnak bizonyul, mint akár a kulturális kód (a nyelv és a jelentés), akár a saját, közvetlen tapasztalat.

\section{Összefoglalás}

A fentiek során azt láttuk, talán sokszorosan igazolva, hogy az individuális cselekvések alapjául szolgáló döntések megértésére irányuló törekvésnek azt az információkombinációt kell feltárnia, amely müködésbe lépett, „,mozgósitásra kerïlt” az adott szituációban. Ha ezt sikerül megtenni, akkor egyidejúleg kapunk választ a cselekvések azonosságára és különbségére is, s emögött felsejlik az az óriásmintázat (Maciverrel szólva: „az individuális tudatok hasonló elemeinek természete"), ahogyan az információs univerzum darabkái eloszlanak az egyes elmék között. Helyesen mondja Maciver, csak a „kollektív tudat” kifejezést cseréljük ki információközösségre: „A társadalmi szerveződések bármely fajtája és bonyolultsági foka elófordulhat. Ha Angliának van kollektív tudata, miért ne lehetne Birminghamnek vagy abban minden kerületnek? Ha egy nemzetnek van kollektív tudata, ugyanígy van egy egyháznak és egy szakszervezetnek is. És kell hogy legyenek olyan kollektív tudataink, melyek részei nagyobb kollektív tudatoknak, és olyan kollektív tudataink is, melyek átfedésben vannak más kollektív tudatokkal."

Az információközösség mint állapot akkor jön létre, amikor egy információ (vagy elemi információk kombinációjából álló információs alakzat) már legalább két emberi elmében megtalálható. Az adott információs alakzatok birtoklásával jellemezhető csoportot is hívhatjuk információközösségnek. Az egyéni, az individuális az egymásra torlódó információközösségek metszéspontján alakul ki, ahogy a fizikai attribútumkombinációk egyedisége különbözteti meg egymástól az alacsonyabb rendú élólényeket.

Az információk vagy információkombinációk - összetettségüktól függetlenül természetük szerint ugyanolyanok. Mintázatok az agyban, amelyek időról időre reflektálnak valamilyen, az egyed szempontjából fontos valósághelyzetre, és szakadatlanul alakulnak, transzformálódnak és átíródnak a tapasztalat pörölycsapásai alatt. „A számtalan egyedi tudatban jelen levô részek kölcsönösen utalnak egymásra, és kiegészítik egymást, s együtt építik fel azt a rendszert, mely kizárólag belólük áll”: ami McDougall szerint „csak a tudat fogalmaival írható le”, valójában az információk összemberi készletét jelenti, amelynek az egyes információközösségek csak bizonyos részhalmazait birtokolják. Az összemberi információkészlet elenyészóen kis darabjaira igaz, hogy valamennyi ember közösen birtokolja azokat: cserébe ott van az individuális tudattartalmak felhốje, amely azáltal tartja mozgásban az információközösségeket, hogy szakadatlanul a megosztásra törekszik.

\footnotetext{
${ }^{38}$ Ennek az irodalmi „tankönyve”, „kötelező olvasmánya” Mihail Solohov Azúrkék pusztn címú novellagyújteménye (Magvetô, 1981).
} 
Tegyük fel újra a kérdést: vajon szükség van-e olyan „keretfogalomra”, modellre, amely az egyes, azonosítható információs alakzatok és az azokat tartalmazó emberi elmék egymást sokszorosan átfedő közös halmazait jeleníti meg?

A parszimónia tudományfilozófiai elve arra biztat, hogy a szükséges mértéken felül ne szaporítsuk az entitásokat (,entia non sunt multiplicanda praeter necessitatem”). De mi itt a szükséges mérték? Az információközösség nem a társadalomkutató absztrakciója, hanem létezố entitás: valóságos agyakban valóságos fizikai mintázok hordozzák, s amíg akár egyetlen információnyi különbség is értelmezi az eltérő viselkedést, addig a modellnek az egyetlen információnyi különbségre is érzékenynek kell lennie.

Az információközösség valójában mégis csak ,elókészítô” kategória. Pár sorral feljebb „keretfogalomnak” neveztem, mert önmagában nem elmélet, hanem csupán egy majdani elméleti összegzéshez szükséges konceptuális váz egyik lehetséges alkotója. Az elốrelépéshez az információs univerzumba kell mélyebben behatolni, hogy sikerüljön feltárni „az emberi ismeretek helyesen értelmezett hierarchikus tagozódását” "39 és evolúciós dinamikáját.

${ }^{39}$ Ramón y Cayal: i.m. 54. 